American Journal of Agricultural and Biological Sciences 5 (3): 385-388, 2010

ISSN 1557-4989

(C) 2010 Science Publications

\title{
Breaking Bud Dormancy and Different Shade Levels for Production of Pot and Cut Cucurma alismatifolia
}

\author{
L.A. Thohirah, C.L.S. Flora and N. Kamalakshi \\ Department of Crop Science, Faculty of Agriculture, University Putra Malaysia, \\ 43400 Serdang, Selangor Darul Ehsan, Malaysia
}

\begin{abstract}
Problem statement: Cucurma alismatifolia is a member of the family Zingiberaceae. It is widely grown in Thailand and is also a highly demanded plant in Holland and Israel where it is grown for cut flowers and as pot plants. C. alismatifolia has a good potential as a new flowering crop in the floriculture industry. The development of new flowering pot plants is of interest to commercial growers, nurserymen as well as hobbyists. Noted for its showy inflorescence and unique foliage, this plant is long lasting and durable. It is an herbaceous with short fleshy rhizomes and tuberous roots, often with a dormancy period. Breaking of the bud dormancy on the rhizomes of $C$. alismatifolia is very important as to overcome the problem of eye bud emergence and to provide planting material throughout the year. There is little information on the optimum production environment and cultivation practices of this species. Approach: This study reported on the study of plant morphology, the effects of BAP and ethephon in breaking bud dormancy of $C$. alismatifolia and the effects of different shade levels on the growth and flowering of $C$. alismatifolia. Results: BAP at $100 \mathrm{mg} \mathrm{L}^{-1}$ recorded the most number of eye buds appearance while ethephon at $750 \mathrm{mg} \mathrm{L}^{-1}$ gave the most number of eye emergence. Data obtained shown that the optimum shade level for the production of C. alismatifolia potted plant was at $30 \%$. Conclusion: For commercial production of C. alismatifolia as a cut flower, a shade level of $70 \%$ is highly recommended, as it exhibits a good characteristic for a cut flower at this shade level.
\end{abstract}

Key words: Cucurma alismatifolia, plant morphology, bud dormancy, flowering, commercial value

\section{INTRODUCTION}

Cucurma alismatifolia is a member of the family Zingiberaceae. It is grown widely in Thailand (Skornickova, 2006) and is also a highly demanded plant in Holland and Israel where it is grown for cut flowers and as pot plants. C. alismatifolia has a good potential as a new flowering crop in the global floriculture industry of our country and development of new flowering pot plants is of interest to commercial growers, nurserymen as well as hobbyist. Noted for its showy inflorescence and unique foliage, the inflorescence is long lasting and durable.

The inflorescence bracts (modified leaves) are nearly always differentiated into two types (Fig. 1A). The basal bracts are essentially green and persistent. These bracts are fertile and bear up to seven more or less concealed flowers. The upper colored bracts form the pink part of the inflorescence. The bloom which is held above the foliage does look like a tulip. C. alismatifolia is a herbacoeus perennial with short fleshy rhizomes and tuberous roots, often with a dormancy period (Fig. 1B) (Burch et al., 1987).

As an ornamental ginger, propagation of the species is mainly through their geophytic units, or rhizomes. The rhizomes are thus the major source of food for the plant. In general, the total growing period is 8 months, mainly during the rainy season (March to October) and flowering occurs only after 4 months from the day of germination. Flowering is followed by initiation of new rhizome. During the dry season, the rhizomes become dormant. Rhizomes in commercial production are harvested at this time for commercialization. Breaking of bud dormancy on rhizomes of $C$. alismatifolia is very important as to overcome the problem of eye bud emergence and to produce the plant year round. Inflorescence stalks of this species arise from a pseudostem and often tend to extend a long way from the foliage, which lowers the commercial value of the plants. Potted cucurma is most often grown to a standard of 1.5-2 times the height of the container. On the other hand, a long inflorescence spike is beneficial for the cut flower market.

Corresponding Author: L.A. Thohirah, Department of Crop Science, Faculty of Agriculture, University Putra Malaysia, 43400 Serdang, Selangor Darul Ehsan, Malaysia Tel: +603-8946 6947 Fax: +603-8943 5973 


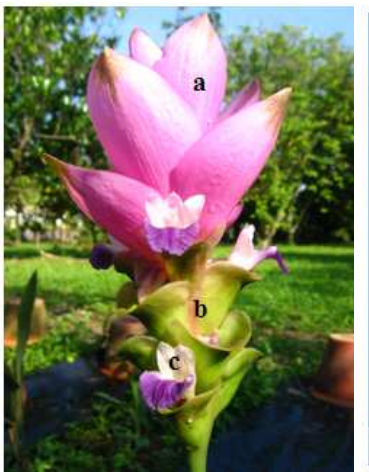

(A)

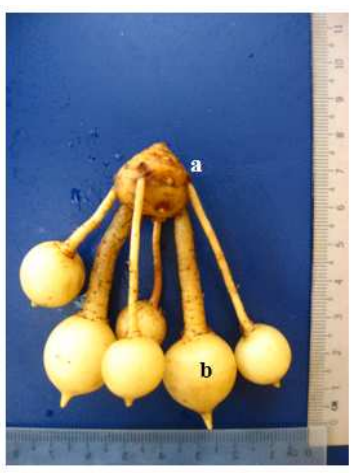

(B)
Fig. 1: (A) Inflorescence of C. alismatifolia; (a) Upper bract, pink; (b) lower bract, green; (c) true flower; (B). Rhizomes of C. alismatifolia; (a) rhizome; (b) storage root

Shading plays an importnat role in the growth and flowering of many flowering ornamentals. According to (Treshow, 1970), light intensity is not only important in the photosynthesis process and food production in plants but is also important for plant growth and development. There is little information on the optimum production environment and cultivation practices of this species. Therefore, this study attempts to cover the study on the effects of BAP and ethephon in breaking bud dormancy and to evaluate the various shade levels on the growth and flowering responses of Curcuma alismatifolia.

\section{MATERIALS AND METHODS}

Two separate experiments were conducted to study the effects of BAP and ethephon in breaking bud dormancy of $C$. alismatifolia. In experiment 1 , six concentrations of BAP at $0,50,100,150,200$ and 250 $\mathrm{mg} \mathrm{L^{-1 }}$ were applied, while in experiment 2 , six different levels of ethephon concentration was used, with 0 (control), 150, 300, 450, 600 and $750 \mathrm{mg} \mathrm{L}^{-1}$. BAP and ethephon treatments were applied to rhizomes by soaking into the sterilized BAP and ethephon for about $30 \mathrm{~min}$. The rhizomes was then taken out and placed on moistened cotton under sterilized condition in flasks. The flasks were then placed in the incubation room at room temperature of $2 \pm 3^{\circ} \mathrm{C}$ for 24 days under $16 \mathrm{~h}$ photoperiod $(18 \mu \mathrm{mol}$ $\mathrm{m}^{-2} \mathrm{sec}^{-1}$ ). Data on days to visible bud, percentage of bud sprouts, shoot length and rhizome weight gain was taken. The data collected was analyzed by Statistical Analysis Software (SAS) version 9.1 and means were separated by Duncan's Multiple Range Test (DMRT).
In the study of effects of different levels of shading on growth and flowering of Cucurma alismatifolia, the rhizomes were treated with Benlate ${ }^{\circledR}$ before planted in a mixture of 1 top soil: 2 organic matter (cocopeat and paddy husk). Plants were grown under four levels of shading. T1 $(0 \%$, without using black net); T2 $(30 \%$ shade); T3 (50\% shade) and T4 (70\% shade). The average light intensity measured for $\mathrm{T} 1, \mathrm{~T} 2, \mathrm{~T} 3$ and $\mathrm{T} 4$ was $1108.67,645.32,402.08$ and $296.86 \mu \mathrm{mol} \mathrm{m} \mathrm{m}^{-2}$ $\mathrm{sec}^{-1}$ respectively. One rhizome was planted per pot of $25 \mathrm{~cm}$ diameter. Twenty plants were grown under each treatment. Fertilizer NPK Blue was applied once a month at a recommended rate of $5 \mathrm{~g}$ per pot. Malathion ${ }^{\circledR}$ and Benlate ${ }^{\circledR}$ were sprayed weekly to prevent the plants from unwanted pest and diseases. Mitac ${ }^{\circledR}$ was sprayed to control red spider mites. Growth and flowering parameters measured were plant height, number of days to shoot emergence, number of days to first visible bud, number of days to a thesis, number of days to senescence, flower stalk length and inflorescence length. Flower stalk was measured form the point of growth to the tip of the inflorescence. Inflorescence length was measured by the vertical length of the colored inflorescence. The data collected was analyzed by Statistical Analysis Software (SAS) version 9.1 and means were separated by Tukey's Honesty Significant Difference (HSD) test.

\section{RESULTS}

In experiment 1 , the number of eye bud breaks was reduced as the concentration of BAP increased. There was significant effect on the number of days to visible bud. BAP at $100 \mathrm{mg} \mathrm{L}^{-1}$ gave the earliest time for visible bud appearance as compared to control and the other concentrations. There were significant differences for rhizome weight gain among treatments. However, no significant differences were observed among treatments for shoot length (Table 1). There was an increase in the time for number of days to visible bud formation with increasing BAP concentration.

In experiment 2, the number of eye bud emergence on the rhizomes of $C$. alismatifolia increased as the concentration of ethephon increased. There were significant effects for days to visible buds, percentage of bud sprouts (\%), shoot length $(\mathrm{cm})$ and rhizome weight gain $(\mathrm{g})$ (Table 2). Ethephon at $750 \mathrm{mg} \mathrm{L}^{-1}$ gave the most eye buds emergence that is at 5 eye buds while at $150 \mathrm{mg} \mathrm{L}^{-1}$ and at control $\left(0 \mathrm{mg} \mathrm{L}^{-1}\right)$ eye buds emergence was at 2.25 eye buds. There were significant differences on increased in rhizome weight gain among treatment as well as for shoot length. 
Am. J. Agri. \& Biol. Sci., 5 (3): 385-388, 2010

Table 1: Effects of BAP on days to visible bud, percentage of bud sprouts $(\%)$, shoot length $(\mathrm{cm})$ and rhizome weight gain $(\mathrm{g})$

\begin{tabular}{lllll}
\hline $\begin{array}{l}\text { Treatment } \\
\left(\mathrm{mg} \mathrm{L}^{-1}\right)\end{array}$ & $\begin{array}{l}\text { Days to } \\
\text { visible bud }\end{array}$ & $\begin{array}{l}\text { Percentage of } \\
\text { bud sprouts }(\%)\end{array}$ & $\begin{array}{l}\text { Shoot length } \\
(\mathrm{cm})\end{array}$ & $\begin{array}{l}\text { Rhizome } \\
\text { weight gain }(\mathrm{g})\end{array}$ \\
\hline 0 & $5.5 \mathrm{a}^{\mathrm{z}}$ & $15.53 \mathrm{~b}$ & $0.31 \mathrm{a}$ & $0.18 \mathrm{abc}$ \\
50 & $4.3 \mathrm{ab}$ & $15.63 \mathrm{~b}$ & $0.26 \mathrm{a}$ & $0.13 \mathrm{bc}$ \\
100 & $3.3 \mathrm{~b}$ & $23.75 \mathrm{a}$ & $0.36 \mathrm{a}$ & $0.26 \mathrm{ab}$ \\
150 & $3.5 \mathrm{~b}$ & $20.50 \mathrm{ab}$ & $0.32 \mathrm{a}$ & $0.27 \mathrm{a}$ \\
200 & $4.8 \mathrm{ab}$ & $13.54 \mathrm{~b}$ & $0.28 \mathrm{a}$ & $0.13 \mathrm{bc}$ \\
250 & $5.5 \mathrm{a}$ & $15.66 \mathrm{~b}$ & $0.27 \mathrm{a}$ & $0.10 \mathrm{c}$ \\
\hline
\end{tabular}

${ }^{\bar{z}}$ : Means within the same column followed by a common letter are not significantly different at $\mathrm{p}<0.05$ based on Duncan's multiple range test

Table 2: Effects of ethephon on days to visible bud, percentage of bud sprouts $(\%)$, shoot length $(\mathrm{cm})$ and rhizome weight gain $(\mathrm{g})$

\begin{tabular}{|c|c|c|c|c|}
\hline $\begin{array}{l}\text { Treatment } \\
\left(\mathrm{mg} \mathrm{L}^{-1}\right)\end{array}$ & $\begin{array}{l}\text { Days to } \\
\text { visible bud }\end{array}$ & $\begin{array}{l}\text { Percentage of } \\
\text { bud sprouts }(\%)\end{array}$ & $\begin{array}{l}\text { Shoot length } \\
(\mathrm{cm})\end{array}$ & $\begin{array}{l}\text { Rhizome } \\
\text { weight gain }(\mathrm{g})\end{array}$ \\
\hline 0 & $5.50 \mathrm{a}^{\mathrm{y}}$ & $12.88 \mathrm{~b}$ & $0.27 b$ & $0.14 b$ \\
\hline 150 & $4.50 \mathrm{ab}$ & $11.39 \mathrm{~b}$ & $0.31 \mathrm{~b}$ & $0.15 b$ \\
\hline 300 & $4.00 \mathrm{bc}$ & $15.90 \mathrm{ab}$ & $0.27 \mathrm{~b}$ & $0.18 b$ \\
\hline 450 & $3.75 b c$ & $15.00 \mathrm{~b}$ & $0.30 \mathrm{~b}$ & $0.16 \mathrm{~b}$ \\
\hline 600 & $3.00 \mathrm{c}$ & $22.95 \mathrm{a}$ & $0.36 \mathrm{ab}$ & $0.23 b$ \\
\hline 750 & $3.50 \mathrm{bc}$ & $22.50 \mathrm{a}$ & $0.44 \mathrm{a}$ & $0.41 \mathrm{a}$ \\
\hline
\end{tabular}

${ }^{\mathrm{y}}$ : Means within the same column followed by a common letter are not significantly different at $\mathrm{p}<0.05$ based on Duncan's multiple range test

Table 3: Effects of different shade levels on plant height, number of days to shoot emergence, number of days to first visible buds, number of days to anthesis, number of days to senescence, flower stalk length and inflorescence length of $C$. alismatifolia

\begin{tabular}{llllllll}
\hline Treatments & $\begin{array}{l}\text { Plant height } \\
(\mathrm{cm})\end{array}$ & $\begin{array}{l}\text { Number of days to } \\
\text { shoot emergence }\end{array}$ & $\begin{array}{l}\text { Number of days to } \\
\text { first visible buds }\end{array}$ & $\begin{array}{l}\text { Number of days } \\
\text { to anthesis }\end{array}$ & $\begin{array}{l}\text { Number of days } \\
\text { to senescence }\end{array}$ & $\begin{array}{l}\text { Flower stalk } \\
\text { length }(\mathrm{cm})\end{array}$ & $\begin{array}{l}\text { Inflorescence } \\
\text { length }(\mathrm{cm})\end{array}$ \\
\hline $0 \%$ & $39.080 \mathrm{~d}^{\mathrm{x}}$ & $50.800 \mathrm{a}$ & $84.600 \mathrm{a}$ & $91.200 \mathrm{a}$ & $46.500 \mathrm{a}$ & $56.480 \mathrm{~b}$ & $12.610 \mathrm{a}$ \\
$30 \%$ & $58.390 \mathrm{c}$ & $28.600 \mathrm{~b}$ & $60.700 \mathrm{~b}$ & $68.400 \mathrm{~b}$ & $42.500 \mathrm{ab}$ & $57.850 \mathrm{~b}$ & $11.920 \mathrm{a}$ \\
$50 \%$ & $71.820 \mathrm{~b}$ & $25.300 \mathrm{bc}$ & $55.800 \mathrm{~b}$ & $62.700 \mathrm{~b}$ & $35.300 \mathrm{bc}$ & $74.060 \mathrm{a}$ & $10.840 \mathrm{a}$ \\
$70 \%$ & $82.700 \mathrm{a}$ & $23.200 \mathrm{c}$ & $57.000 \mathrm{~b}$ & $63.800 \mathrm{~b}$ & $37.600 \mathrm{c}$ & $78.250 \mathrm{a}$ & $11.280 \mathrm{a}$ \\
Statistical & $* *$ & $* *$ & $* *$ & $* *$ & $* *$ & $* *$ & $\mathrm{~ns}$
\end{tabular}

differences

$\overline{\mathrm{x}}$ : Means within the same column followed by a common letter are not significantly different based on Tukey Studentized range test at $(\mathrm{p}<0.05)$ level

Ddifferent levels of shading had significant effect on the growth and flowering of Cucurma alismatifolia. Results obtained for growth and flowering parameters shown that there were significant differences for plant height, number of days to shoot emergence, number of days to first visible bud, number of days to a thesis, number of days to senescence and flower stalk length. However, there was no significant difference in inflorescence length (Table 3). In general, plant height increased with increasing shade level. The increment in plant height was 52.7 under $70 \%$ shade and it increased by 29.4 and $13.2 \%$ fewer than 30 and $50 \%$ shading respectively, compared to $0 \%$ shade. Shading also shortened the duration for shoot to emerge. Plants under $0 \%$ shading emerged very late (51 days after planting) as compared to plants grown under 30, 50 and $70 \%$ shading. On the other hand, plants grown at $70 \%$ shading emerged 28 days earlier than those in the control plot ( $0 \%$ shading). Number of days to first visible bud and days to anthesis was highly significant at the different shade levels. The day visible buds were noticed and plants bloom was the earliest for plants grown under 50\% shade. Flower longevity was longest
(47 days) under 0 shade, 30 (43 days) and 70\% shade (38 days). Plants grown under 50\% shade were the earliest to senesce at 35 days after flowering. Flower last longer for blooms at $0 \%$ shade. Flower stalk length increased with increasing shade levels. There was no significant difference between the treatments for inflorescence length (Table 3).

\section{DISCUSSION}

BAP at the concentration of $100 \mathrm{mg} \mathrm{L}^{-1}$ has been shown to successfully breaking bud dormancy of rhizome of Curcuma cordata and produced the highest mean shoot length. BAP also influenced the number of shoots of Zingiber officinale at the concentration of $1 \mathrm{mg} \mathrm{L}^{-1}$ using liquid culture (Arimuna et al., 2000).

The rhizome of Zingiber officinale Roscoe 'Chinese' treated with $750 \mathrm{ppm}$ of ethephon produced the highest number of shoots, highest mean shoot length and highest rhizome weight compared with untreated rhizome (Furutani et al., 1985). Furutani and Nagao (1986) also reported that the number of shoots of Zingiber officinale increase with the increasing 
concentration of ethephon. Ethephon has been found to assist in swelling and bulb formation on the bulbs that were not exposed to long day treatment. Normally, a long day treatment between 12 and $16 \mathrm{~h}$ are required for bulb formation (Levy and Kedar, 1970; CorralesMaldonado et al., 2010; Mahadtanapuk et al., 2007).

Increasing shade levels increased plant height. C. alismatifolia and the other ornamental ginger produce plants with tall inflorescences and this result in unmarketable potted plants due to excessive height (Nelson, 2002). Paz (2003) have concluded that to produce a plant of good quality to the market, potted plants of $C$. alismatifolia must be grown in full sun. Shading provides a plant with lower soil temperature. Evenson et al. (1970) indicated that an optimum soil temperature greater than $25^{\circ} \mathrm{C}$ but less than $30^{\circ} \mathrm{C}$ is for the germination and early growth of ginger is required for $3^{1 / 2}$ to 4 weeks for shoot to emerge. Rhizomes of C. alismatifolia should be planted under shade so as to shorten the germination process and to further enhance commercial production of Cucurma. The growth of plants grown under shading was faster as compared to that of control. This could be due to the shorter time taken during the emergence of shoots for plants grown at 30,50 and $70 \%$ shade. This is probably because shoot emergence of plants at $0 \%$ shade is the latest and more food reserved occurred at this shade level. According to Kuehny (2001), the postproduction longevity of this species is about 40 days. Paz (2003) reported that plant height and flower height for potted C. alismatifolia, when grown at 30 and $60 \%$ shade, was significantly taller by 9 and $13 \mathrm{~cm}$ respectively.

\section{CONCLUSION}

For commercial production of $C$. alismatifolia as a cut flower, a shade level of $70 \%$ is highly recommended, as it exhibits a good characteristic for a cut flower at this shade level.

\section{REFERENCES}

Arimuna, C.T., F.L. Finger and V.W.D. Casali, 2000. Effect of ANA and BAP on ginger (Zingiber officinale Roscoe) sprouting in solid and liquid medium. Revista-Brasileirade Plantas Med., 2: 23-26.

Burch, D.G., E.W. Demmy and H. Donselman, 1987. Gingers for Florida gardens. Proc. Flo. State Hort. Soc., 100: 222-226.
Evenson, J.P., C.J. Asher, J. Standley and G. Walduck, 1970. The effect of continuous soil temperature on the early growth of ginger rhizomes. Proceeding of the 2nd International Trop. Root and Tuber Crops Symposium, Aug. 1970, University of Hawaii, Hawaii, pp: 162-162.

Corrales-Maldonado, C., M.A. Martinez-Tellez, A.A. Gardea, A. Orozco-Avitia and I. Vargas-Arispuro, 2010. Organic alternative for breaking dormancy in table grapes grown in hot regions. Am. J. Agric. Biol. Sci., 5: 143-147. http://www.scipub.org/fulltext/AJAB/AJAB52194 -198.pdf

Furutani, S.C. and M.A. Nagao, 1986. Influence of daminozide, gibberellic acid and ethephon on flowering, shoot growth and yield of ginger. HortScience, 21: 428-429. http://cat.inist.fr/?aModele $=$ afficheN\&cpsidt $=8715$ 895

Furutani, S.C., J. Villanueva and M.J. Tanabe, 1985. Effect of Ethephon and heat on the growth and yield if edible ginger. HortScience, 20: 392-393.

Kuehny, J., 2001. Potting ornamental ginger. Greenhouse Production News. http://www.onhort.com/articles/keuhny.pdf

Levy, D. and N. Kedar, 1970. Effect of ethereal on growth and bulb initiation in onion. HortScience, 5: 80-82.

Mahadtanapuk, S., M. Sanguansermsri, R.W. Cutler, V. Sardsud and S. Anuntalabhochai, 2007. Control of anthracnose caused by Colletotrichum musae on Curcuma alismatifolia Gagnep. Using antagonistic Bacillus spp. J. Agric. Biol. Sci., 2: 54-61. http://www.scipub.org/fulltext/AJAB/AJAB225461.pdf

Nelson, P.V., 2002. Greenhouse Operation and Management. 6th Edn., Prentice Hall, New Jersey, ISBN: 10: 0130105775, pp: 692.

Paz, P.M., 2003. Rhizome manipulation affects growth and development of ornamental gingers. M.S. Thesis, Louisiana State University. http://etd.lsu.edu/docs/available/etd-1110103154436/unrestricted/Paz_thesis.pdf

Skornickova, J. 2006. Cucurma-stunning beauty, hidden treasure. Gardenwise, 27: 4-4.

Treshow, M., 1970. Environment and Plant Response. 1st Edn., McGraw Hill, New York, pp: 422. 